\title{
Sensitive detection and apoptotic cell death induction of adult T-cell leukemia/lymphoma (ATL) cells with photodynamic actions
}

\author{
Takashi Oka ${ }^{*}$, Hirofumi Fujita ${ }^{2}$, Lamia Abd Al-Kader ${ }^{1}$, Ichiro Murakami ${ }^{3}$, Atae Utsunomiya ${ }^{4}$, Tadashi Yoshino ${ }^{1}$ \\ From 16th International Conference on Human Retroviruses: HTLV and Related Viruses \\ Montreal, Canada. 26-30 June 2013
}

Adult $\mathrm{T}$ cell leukemia/lymphoma (ATL) is an aggressive malignant disease of $\mathrm{CD} 4$ positive $\mathrm{T}$ lymphocytes caused by infection with human $\mathrm{T}$ cell leukemia virus type I (HTLV-I). HTLV-1 causes ATL in 3-5\% of infected individuals after a long latent period of 40 to 60 years. The acute and lymphoma types are aggressive ATL characterized by resistance to chemotherapy and a poor prognosis. Leukemia/lymphoma cells and rapidly proliferating cells preferentially accumulate endogenous photosensitizer protoporphyrin IX (PpIX) when supplemented with 5-aminolevulinic acid (ALA). Treatment with 1mM ALA for $48 \mathrm{~h}$ induced 10 to 100 times accumulation of PpIX in ATL leukemic cell lines and HTLV-I $(+)$ T cell lines than that in healthy PBMCs. Specific induction of apoptosis was observed after $10 \mathrm{~min}$ light exposure $\left(28 \mathrm{~mW} / \mathrm{cm}^{2}\right)$ using Na-Li lamp in ATL leukemic cell lines and HTLV-I (+) $\mathrm{T}$ cell lines. ATL patient PBMC specimen showed strong accumulation of PpIX with the treatment of ALA compared to the healthy donor and HTLV-I carrier PBMCs, which could be useful for the diagnostic purposes and monitoring the patient status with high sensitivity. Photodynamic therapy is potentially hopeful treatment especially for lymphoma type ATL as a relatively selective, minimal or no scarring, non-invasive, safe, simultaneous and repeatable multiple lesions treatable modality.

\section{Authors' details}

'Department of Pathology, Graduate School of Medicine, Dentistry and

Pharmaceutical Sciences, Okayama University, Okayama, Japan.

2Department of Cytology and Histology, Graduate School of Medicine,

Dentistry and Pharmaceutical Sciences, Okayama University, Okayama, Japan.

${ }^{3}$ Department of Molecular Pathology, Tottori University Medical School,

\footnotetext{
* Correspondence: oka@md.okayama-u.ac.jp

'Department of Pathology, Graduate School of Medicine, Dentistry and

Pharmaceutical Sciences, Okayama University, Okayama, Japan

Full list of author information is available at the end of the article
}

Yonago, Japan. ${ }^{4}$ Department of Hematology, Imamura Bun-in Hospital, Kagoshima, Japan.

Published: 7 January 2014

\section{doi:10.1186/1742-4690-11-S1-P5}

Cite this article as: Oka et al:: Sensitive detection and apoptotic cell death induction of adult T-cell leukemia/lymphoma (ATL) cells with photodynamic actions. Retrovirology 2014 11(Suppl 1):P5.
Submit your next manuscript to BioMed Central and take full advantage of:

- Convenient online submission

- Thorough peer review

- No space constraints or color figure charges

- Immediate publication on acceptance

- Inclusion in PubMed, CAS, Scopus and Google Scholar

- Research which is freely available for redistribution
() Biomed Central 